\title{
Collaborative Study Brazil-Portugal: Validation of HPV Lyophilized Samples
}

\section{Maria Elizabeth Menezes ${ }^{1 *}$, Frederico Tourinho² ${ }^{2}$ José Abol Corrêa ${ }^{3}$, Ana Paula Faria ${ }^{4}$ and Mario Cunha ${ }^{5}$}

${ }^{1}$ Sociedade Brasileira de Análises Clínicas (SBAC), Programa Nacional de Controle de Qualidade, Rio de Janeiro, Brazil

${ }^{2}$ Centro Universitário Avantis (Uniavan), Polo Florianópolis, Santa Catarina, Brazil

${ }^{3}$ Sociedade Brasileira de Análises Clínicas (SBAC), Programa Nacional de Controle de Qualidade, Rio de Janeiro, Brazil

${ }^{4}$ Instituto Nacional de Saúde Dr. Ricardo Jorge, Programa Nacional de Avaliação Externa da Qualidade, Lisboa, Portugal

${ }^{5}$ Instituto Português de Oncologia de Lisboa, Serviço de Patologia Clínica - Laboratório de Virologia, Lisboa, Portugal

*Corresponding Author: Maria Elizabeth Menezes, Sociedade Brasileira de Análises Clínicas (SBAC), Programa Nacional de Controle de Qualidade, Rio de Janeiro, Brazil.
Received: March 17, 2020

Published: June 17, 2020

(C) All rights are reserved by Maria Elizabeth Menezes., et al.

\begin{abstract}
HPV is an important virus that is responsible for more than $99 \%$ of cancer in women. Preparation and validation of lyophilized samples to use as a control of molecular biology tests for HPV is very important. There are several techiniques to performer molecular test to detecte HPV however, it is necessary that their is a sample control whith can be used independent of methodology. Validation of lyophilized samples by different molecular techniques to have harmonized standards relies on consistent control.
\end{abstract}

Keywords: HPV; Molecular Biology; Quality Control; DNA

\section{Abbreviation}

HPV: Human Papilloma Virus; EQA: External Quality Assurance; PNCQ: Programa Nacional de Controle de Qualidade; INSA: Instituto Nacional de Saude Dr. Ricardo; IPOL: Instituto Português de Oncologia Lisboa; IBIOTECNO: Instituto Biotecnologia

\section{Introduction}

Human Papillomavirus Virus (HPV), cause genital infection and is the most common sexually transmitted disease at the sexually active population. Infection with this virus can cause genital warts, intraepithelial neoplasias and invasive cervical cancer. Recent studies have shown that high-risk HPV is present in more than $99.7 \%$ of cervical carcinomas worldwide. Given the importance of the disease it causes, and the use of different laboratorial techniques, mainly of molecular biology, it is mandatory to have an External Quality Assurance (EQA) program based on harmonized standards that rely on consistent controls. The control of Molecular Biology techniques is absolutely necessary for the quality assurance of the results, the tracing and monitoring the performance of the reagents. However, one of its limitations is the stability, ho- mogeneity of the material, as well as the control samples adequate for the parameter to be analyzed. The Programa Nacional de Controle de Qualidade (PNCQ), in order to fill this gap, lyophilized the HPV samples to be used as a control. In order to do the validation and to test the reproducibility of these lyophilized samples, PNCQ sent to Instituto Nacional de Saude Dr. Ricardo (INSA) and the Instituto Português de Oncologia Lisboa (IPOL)to be analysed by different methods and reagents in two different countries and different laboratories. Control samples adequate for the parameter to be analyzed. The PNCQ, in order to fill this gap, lyophilised the HPV samples control. In order to do the validation and to test the reproducibility of these lyophilized samples, PNCQ sent to INSA and the IPOL to be analysed by different methods and reagents in two different countries and different laboratories. Validation of lyophilized samples by different molecular techniques to have harmonized standards that relies on a consistent control [1-4].

\section{Materials and Methods}

Screening for positive HPV was done by Instituto Biotecnologia (IBIOTECNO) 1,500 samples were collected from patients (wom- 
en) and tested for HPV using Hybrid Capture technique in agreement with the manufacturer's Protocol (Qiagen). Negative samples were selected to be used as an HPV negative control. The positive samples for HPV, were divided into three groups: 1- Samples containing HPV of High Risk; 2-Samples containing HPV of Low Risk; 3- Samples containing HPV of High and Low Risk. The samples after lyophilization were tested for group specific again by Hybrid Capture technique, to make sure the concentration was not lost during the process of lyophilization.

The lyophilizaded sample was sent at room temperature to INSA (Laboratório Nacional de Referência das Infecções Sexualmente Transmissíveis - vírus do papiloma humano, vírus herpes genital) and IPOLFG SPCLV (Instituto Português Oncologia de Lisboa Franscisco Gentil, Serviço de Patologia Clinica Laboratório de Virologia) had HPV of high oncogenic potential (HPV-B) and was used for validation of the process, in order to be used as a control. The sample was reconstituted with water free of DNAse and RNAse, DNA extraction and detection/genotyping were done using methodologies described in table 1 .

\begin{tabular}{|c|c|c|}
\hline Institution & $\begin{array}{c}\text { DNA } \\
\text { Extraction }\end{array}$ & Detection/ Genotyping \\
\hline INSA (PT) & $\begin{array}{l}\text { Automatic - } \\
\text { NucliSENS } \\
\text { bioMerieux } \\
\text { easyMAG }\end{array}$ & $\begin{array}{l}\text { Clart HPV } 2 \text { (Genomica) } \\
\text { Primers: MYo9/11 (amplification of 450pb, } \\
\text { L1 region) }\end{array}$ \\
\hline IPO (PT) & $\begin{array}{l}\text { Manual - Qiagen } \\
\text { Vírus Mini kit }\end{array}$ & $\begin{array}{l}\text { Real Time PCR SYBR Green (In House } \\
\text { assay): } \\
\text {-Detection (screening) } \\
\text {-Primers: SPF } 10 \text { (amplification of } 75 \text { bp, L1 } \\
\text { region) } \\
\text {-Accreditation ISO } 15189 \\
\text { INNO-LIPA HPV (Innogenetics): } \\
\text {-Primers: SPF } 10 \text { (amplification of } 65 \text { bp, L1 } \\
\text { region) } \\
\text {-Accreditation ISO } 15189 \\
\text { Papillocheck (Greiner): } \\
\text {-Primers: NA (amplification of } 350 \text { bp, E1 } \\
\text { region) }\end{array}$ \\
\hline $\begin{array}{l}\text { PNCQ } \\
\text { /IBIOTECNO } \\
\text { (BR) }\end{array}$ & Qiagen Kit & $\begin{array}{l}\text { Hybrid Capture } 2 \\
\text {-Discrimination between High Risk and Low } \\
\text { Risk }\end{array}$ \\
\hline
\end{tabular}

Table 1: Methodologies use in DNA extraction detection/genotyping.

\section{Results and Discussion}

The tabulated results (Table 2) present the quantification of the samples "pool" before and after lyophilization. Quantification was performed according to the specifications on the manufacturer "KIT Captura Hibrida" (Qiagen).

The data shows that the viral concentration of the sample was preserved after lyophilization: 2.65 RLUs before lyophilization and 2.33 RLUs after. These results reflect preservation of DNA. In terms of DNA quantification, both Portuguese laboratories obtained good values: at INSA was $21.09 \mathrm{ng} / \mu \mathrm{l}$ and in IPOLFGSPCLV were
$43.09 \mathrm{ng} / \mu \mathrm{l}$. What is important is that the DNA was preserved although there is a difference between the two quantifications. Also, the genotypes detected were similar in all laboratories, despite the different techniques used. In table 2 are the results of the genotyping and table 3 screening tests.

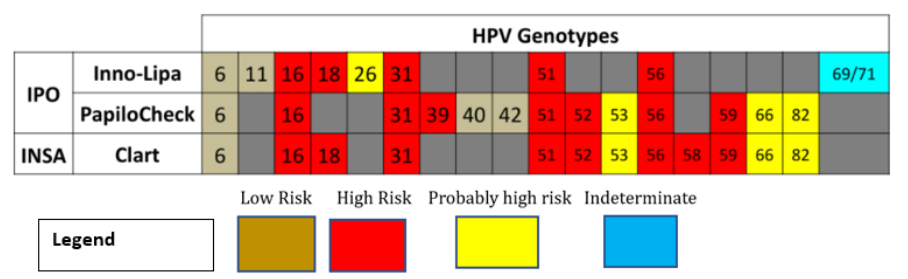

Table 2: HPV genotypes detected in the lyophilized sample by different methodologies used. Genotypes were classified according to Munoz., et al. NEJM 2003 -348 (518-27).

\begin{tabular}{|c|c|c|}
\cline { 3 - 3 } \multicolumn{2}{c|}{} & HPV screening \\
\hline IPO & $\begin{array}{c}\text { Real Time PCR } \\
\text { SYBR Green }\end{array}$ & Result: Detected $(\mathrm{Ct}=26,17 \mathrm{Tm}=73 \circ \mathrm{C})$ \\
\hline PNCQ & Hybrid Capture II & Result: High Risk and Low Risk \\
\hline
\end{tabular}

Table 3: Screening tests.

\section{Conclusion}

This validation between three different laboratories was important for the establishment of a standardized control. Regardless of the DNA extraction and amplification, it was possible to detect HPV DNA. The differences noted in the quantification of DNA are possibly due to the DNA extraction methodology and it doesn't compromise the main goal of this collaboration.

The discrepancies observed between the different kits used for genotyping can be due to the fact that we have several genotypes present in this sample and the different sensibility for each HPV type of the different kits. The presence of so many genotypes in a single sample is due to the sample used is a pool of HC2 positive samples. If genotyping test will be used in the Quality Control, a better sample selection is needed.

The use of lyophilizaded samples in the quality control had the advantage of no especial condition of shipments is needed and a better conservation of the samples is obtain.

It is scheduled the first Pilot scheme in 2020, which will include 10 laboratories with large experience in HPV detection in Portugal. 


\section{Acknowledgements}

FAPESC: Financial support by Fundação de Apoio à Pesquisa de Santa Catarina.

\section{Conflict of Interest}

I declare not exist any financial interest or any conflict of interest.

\section{Bibliography}

1. Zampirolo JA., et al. "Prevalência de HPV de alto e baixo risco pela técnica de biologia molecular (captura híbrida II) em Santa Catarina". Revista Brasileira de Análises Clínicas 39.4 (2007): 265-268.

2. Sanjosé S., et al. "Worldwide prevalence and genotype distribution of cervical human papillomavirus DNA in women with normal cytology: a meta-analysis". Lancet 7.7 (2007): 453459.

3. Kasper JC and Friess W. "The freezing step in lyophilization: Physico-chemical fundamentals, freezing methods and consequences on process performance and quality attributes of biopharmaceuticals". European Journal of Pharmaceutics and Biopharmaceutics 78.2 (2011).

4. Kollicoat IR., et al. "Technology evaluation". Expert Opinion on Drug Delivery 8.5 (2011): 693-703.

\section{Assets from publication with us}

- Prompt Acknowledgement after receiving the article

- Thorough Double blinded peer review

- Rapid Publication

- Issue of Publication Certificate

- High visibility of your Published work

Website: https://www.actascientific.com/

Submit Article: https://www.actascientific.com/submission.php Email us: editor@actascientific.com

Contact us: +919182824667 